\title{
Grant Proposal
}

National Cancer Institute

\section{Source}

National Cancer Institute. Grant Proposal. NCI Thesaurus. Code C71625.

A proposal for a grant. 